How to cite this article:

Author: Czesław Łukianowicz

Title of article: "Review of methods for assessing the geometrical surface structure of rolled products"

Mechanik, No. 12 (2018)

DOI: https://doi.org/10.17814/mechanik.2018.12.192

\title{
Review of methods for assessing the geometrical surface structure of rolled products
}

\author{
CZESŁAW ŁUKIANOWICZ *
}

Dr hab. inż. Czesław Łukianowicz, czeslaw.lukianowicz@tu.koszalin.pl, https://orcid.org/0000-0001-8885-1317 - Katedra Inżynierii

Produkcji, Politechnika Koszalińska, Koszalin, Polska

The paper reviews the optical methods used to measure and evaluate the surface texture of rolled products, such as sheets, strips, etc. Optical methods are particularly useful in conducting the so-called active control of the production processes of rolled products and surface texture assessment.

KEYWORDS: rolled products, surface textures assessment, optical methods

\section{Introduction}

Surface texture or the geometrical surface structure (GSS) in many cases is an important factor determining the quality of products $[1,2]$. For the GSS assessment, among others, universal measuring instruments and systems, e.g. contact profilometers are used.

Requirements for rolled products, including their GSS, have been formulated in relevant standards [3, 4] or technical conditions [5]. Ensuring the correct GSS of these products is associated with the need to assess and control the condition of their surface during the manufacturing process. For this purpose, among others, properly adapted optical methods that allow to actively control the production process of sheets, strips, shapes, etc., are applied. The inspection often takes place during the movement of the test surface and in the conditions of various interferences accompanying the manufacturing process.

In recent years, more and more attention has been devoted to various optical methods and automated control and measuring systems intended for quick and contactless GSS assessment of rolled products.

Among many GSS optical methods of assessment, two groups can be distinguished, used to assess the condition and quality of the surface of rolled products: triangulation methods, primarily used to assess the size and shape of the surface, and scatterometric methods, using the phenomenon of light scattering, intended mainly for assessing the roughness and detection of surface defects.

\section{Triangulation methods}

Triangulation methods are usually based on the use of laser triangulation. In the simplest case, it involves measuring the distance between a point on the surface of the object and a laser light source or a selected reference plane. The surface of the object is illuminated by a small diameter laser beam. The laser light spot visible on the surface of the object is projected with a lens onto the photosensitive surface of the photoelectric detector, which generates a measuring signal depending on the position of the light spot. The angle of inclination of the optical axis of lens in relation to the laser beam directed to the surface is constant and known. Position of laser relative to the lens and photoelectric detector is also constant. Changing the position of the measured object surface along the propagation direction of the laser beam by $\Delta z$ causes a change in the position of the image of the light spot on the photosensitive surface of the detector by $\Delta s$. In this case (fig. 1), the change in the position of the object's surface relative to the initial setting can be measured based on the value of the signal generated by photoelectric detector:

$$
\Delta z=\frac{\Delta s}{M \sin \varphi}
$$


where: $\Delta z$ - surface position change along the laser beam propagation direction, $\Delta s$ - signal corresponding to the change in the position of the laser spot image on the photosensitive surface of the photoelectric detector, $M$ - lens magnification, $\varphi$ - angle between direction of the laser beam and optical axis of lens.

Such a measurement can be regarded as a measurement along the propagation direction of the laser beam, i.e. one-dimensional. The outline of the object's surface using the triangulation method can be determined by scanning the surface with a laser beam in a given cross-section. Scanning requires controlled surface displacement relative to the measuring system.

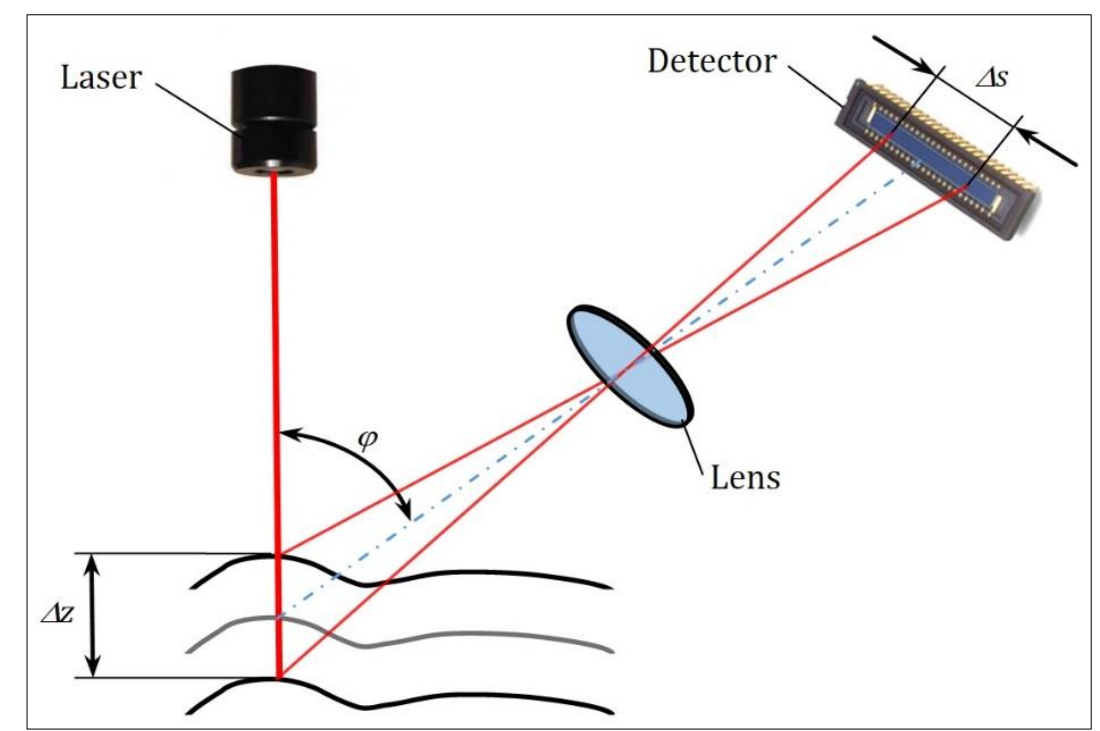

Fig. 1. Measurement of the change in position of the surface outline by the method of laser triangulation

In this case, during scanning, distance of individual points of the surface profile from the laser light source (or reference plane) is measured as a function of the scanning path. Such measurement can be treated as twodimensional.

Another way to obtain a surface outline in a selected cross-section of an object is to project laser light on its surface in the form of a straight line segment, and then - to record and analyze the shape of the image of this line by a computerized vision system set at a known angle in relation to the surface. It is also a two-dimensional measurement. Its idea is illustrated in fig. 2. Unlike surface scanning, this method does not require mutual displacement of the surface and the measuring system, which is its advantage. The method is similar to the longknown method of so-called light cross-section method.

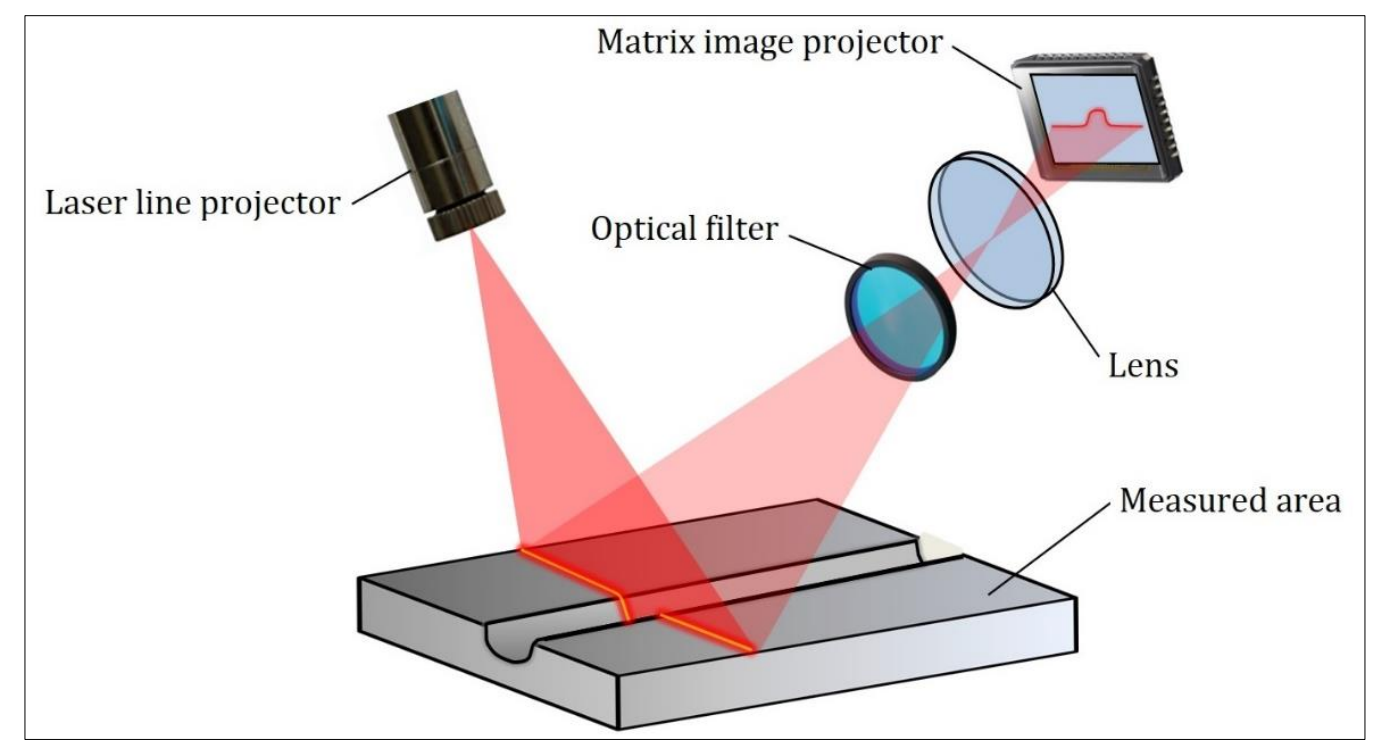

Fig. 2. Surface outline mapping by laser triangulation 
Laser triangulation can also be used for spatial, three-dimensional measurements of the shape of an object's surface. For this purpose, 2D measurements are carried out, with scanning or with projection of a light line, in many subsequent, sufficiently close parallel cross-sections. The most common variant of this method (when used for GSS assessment of rolled products) consists in scanning the surface of the object through a single light line projected onto the surface (or a set of such lines). In this case, the scanning process uses continuous or sequential movement of the object (rolled product) in the processing line. Surface reconstruction of the object is done programmatically, based on a sequence of digitally recorded images. This method of inspection is commonly used to assess the shape and surface defects of long objects, e.g. strips, sheets, sections or rails.

In the steel industry, various sensors and measuring systems are used to control GSS of rolled products [6]. An example is the series of measuring systems for the assessment of GSS, by Swedish company Shapeline AB, which are intended for use in smelters, rolling mills, galvanizing plants, etc. These types of solutions are designed for a specific industry and can be adapted to individual customer needs.

The work [7] discusses in detail the causes of typical deviations in shape and surface defects of rolled products, and also briefly presents the operation and parameters of the integrated VeriFlat measuring system by Shapeline AB. In this system, two laser lines are projected onto the test surface, which is schematically shown in fig. 3. It has been shown in [8] that such system allows for the correction of measurement errors caused by vibrations of the transport system.

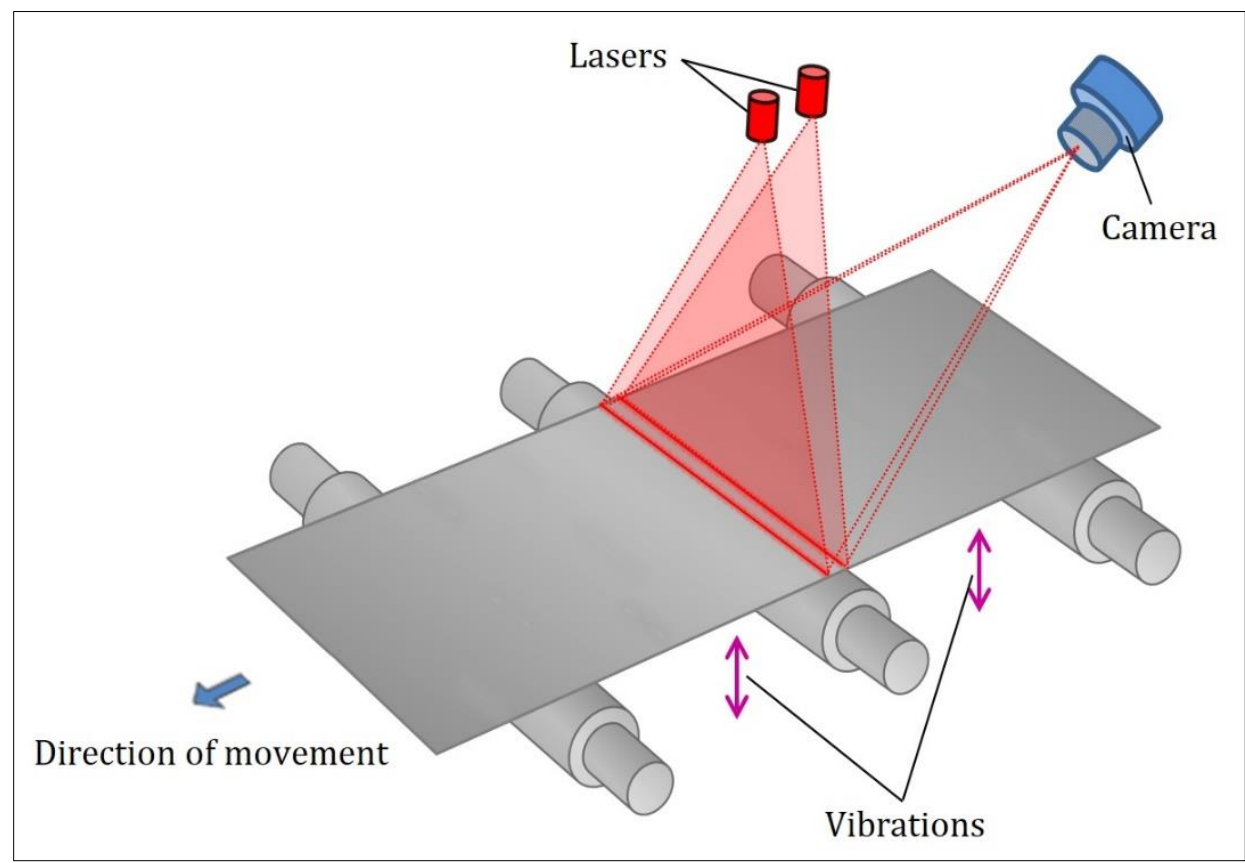

Fig. 3. Diagram of a laser triangulation system with two-line projection, intended for GSS inspection of rolled products

The original GSS control system and surface defects of rolled steel and aluminum products are proposed by the German company IMS Messsysteme $\mathrm{GmbH}$. This system increases the accuracy of triangulation measurements by projecting several pairs of laser lines onto the surface of the object and using CCS (camera cluster systems) with a large number of special miniature video cameras in the detection system [9].

\section{Scatterometric methods}

The name of these GSS assessment methods comes from the English term 'light scattering'. These are contactless methods that allow for a quick and active GSS control during the movement of the measured object. Their advantage is also that the measurement is usually covered by a specific area of the object's surface, and not just a selected single profile.

These methods are characterized by sufficiently high sensitivity and relatively wide measuring range. They make it possible to measure and evaluate unevenness in height from single nanometers to even several micrometers. In the latter case, the sensitivity of the methods is slightly lower, therefore they are less sensitive to vibrations and other factors occurring during the production processes, interfering with the measurement process. 
Among the scatterometric methods used to assess GSS in industry, there are various variants of the so-called differential methods, in which the angular distribution of light intensity scattered by the surface is measured. These methods are also called goniophotometric methods, and in English they are referred to as angle-resolved scattering or differential scattering and are designated with acronyms ARS or DS, respectively. A broader description of scatterometric methods is included, among others, at work [10].

Measurements of the angular distribution of light scattered by some surfaces can be made in the plane of incidence - as shown in fig. 4. In this case, the scattered light intensity is a function of a single variable - scattering angle $\theta$. The graphic image of this function is sometimes called the curve of the angular distribution of scattered light intensity or the scattering indicatrix.

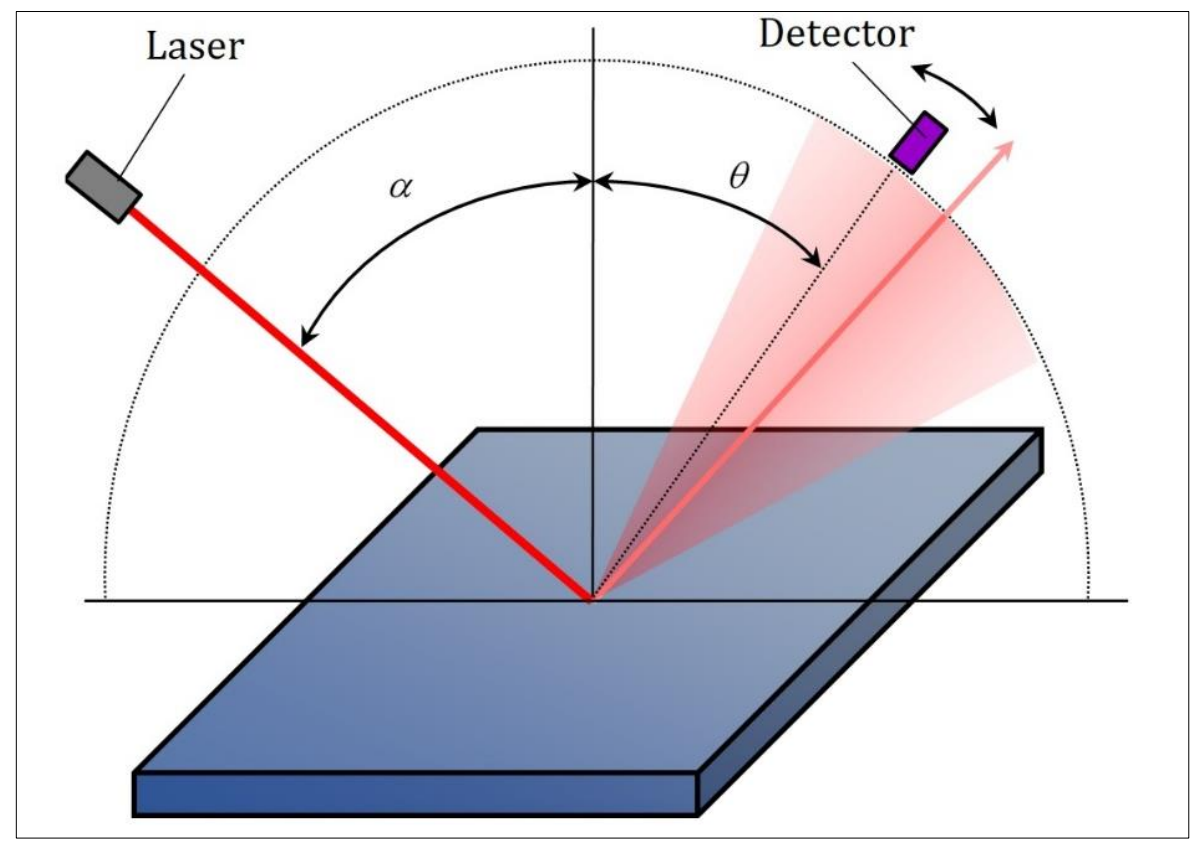

Fig. 4. Principle of determining the angular distribution of scattered light intensity in differential methods

In the case of analysis in 3D space, the light intensity distribution is a function of two variables. The bidirectional reflectance distribution function $(B R D F)$ is defined as the ratio of energy luminance $L_{\mathrm{e}}$ in the direction of dispersion to the radiant power incident on a surface unit.

The energy luminance $L_{\mathrm{e}}$ in a given direction of dispersion is determined inside the solid angle $\mathrm{d} \Omega$. The $B R D F$ function is described by the relationship:

$$
B R D F=\frac{L_{\mathrm{e}}}{P_{\mathrm{i}} / S_{0}}=\frac{\mathrm{d} P / \mathrm{d} \Omega}{P_{\mathrm{i}} \cos \theta}
$$

but:

$$
L_{\mathrm{e}}=\frac{\mathrm{d} P}{S_{0} \mathrm{~d} \Omega \cos \theta}
$$

where: $L_{\mathrm{e}}$ - energy luminance of the illuminated surface in a specific scattering direction, $P_{\mathrm{i}}$ - radiant power falling on the surface, $S_{0}$ - illuminated surface area, $\mathrm{d} P$ - radiant power dispersed inside the elemental solid angle, $\mathrm{d} \Omega$ - elementary solid angle, $\theta$ - scattering angle.

Measurements of angular or spatial distribution of scattered light intensity do not always require scanning with a mobile detector. If the range of scattering angles is small, multi-element, linear or matrix photoelectric detectors can be used.

A good illustration of the use of scatterometric differential methods for GSS assessment of rolled products is the SORM 3plus sensor (superfast optical roughness measurement), developed by the German company EMG Automation GmbH. Fig. 5a shows how this system works. 
The SORM sensor works by quickly moving the system relative to the measured surface and determining based on the analysis of light scattered by the surface - the outline of the surface along the direction of movement.

The discussed system has been used, among others, in the metal industry, including GSS assessment of cold rolled strips [11].

Location of the sensor in the production system is shown in fig. $5 \mathrm{~b}$.

Another example of using the scatterometric methods to assess the surface condition of rolled strips during the manufacture of technical blades is given in [12].

a)

b)

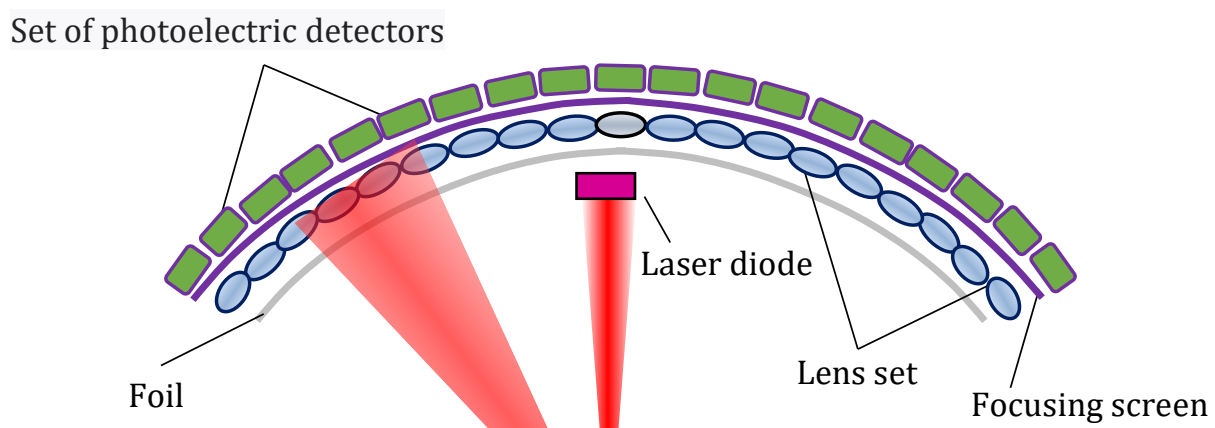

Measured area
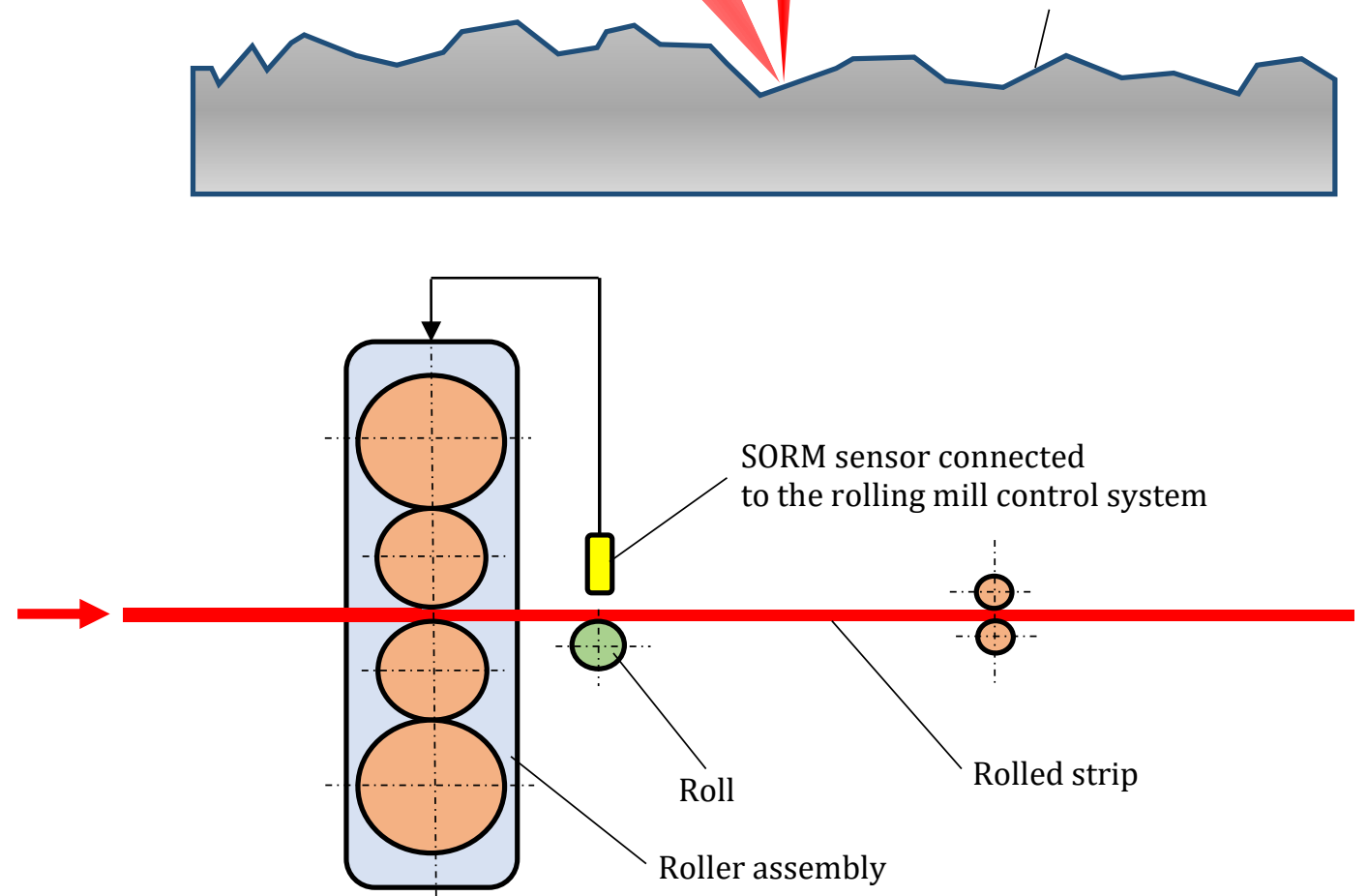

Fig. 5. SORM sensor: a) diagram illustrating the sensor operation principle, b) sensor location in the cold rolled strip production system

\section{Summary}

GSS control and assessment are an important element of rolled products manufacturing processes. The use of optical methods for this purpose helps to ensure the quality of the products manufactured, as well as increases efficiency and reduces the production costs. Systems intended for GSS assessment of products rolled by optical methods are usually in the form of specialized systems, intended for a specific production system. 


\section{REFERENCES}

[1] Adamczak S. „Pomiary geometryczne powierzchni. Zarysy kształtu, falistość i chropowatośc”. Warszawa: WNT, 2008.

[2] Wieczorowski M. „Metrologia nierówności powierzchni - metody i systemy”. Szczecin: ZAPOL, 2013.

[3] PN-EN 10029:2011 Blachy stalowe walcowane na gorąco grubości $3 \mathrm{~mm}$ i większej - Tolerancje wymiarów i kształtu.

[4] PN-EN 13674-1+A1:2011 Kolejnictwo - Tor - Szyna - Część 1: Szyny kolejowe Vignole'a o masie 46 $\mathrm{kg} / \mathrm{m}$ i większej.

[5] Id-106 - Warunki techniczne wykonania i odbioru szyn kolejowych - Wymagania i badania. $\mathrm{Nr}$ ILK3d/518/3/07; Warszawa 2010.

[6] Molleda J., Usamentiaga R., Garcia D.F. "On-Line Flatness Measurement in the Steelmaking Industry". Sensors. 13, 8 (2013): 10245-10272.

[7] Kierkegaard P. "Developments and Benefits from Optical Flatness Measurement in Strip Processing Lines". Congreso y Exposición Nacional de la Industria del Acero, CONAC 2016, Monterrey, Mexico, 1-15, www.shapeline.com/wpcontent/uploads/Shapeline-paper-CONAC-2016-A.pdf (access: 12.10.2018).

[8] Usamentiaga R., Molleda J., Garcia D.F., Bulnes F.G. "Removing vibrations in 3D reconstruction using multiple laser stripes". Optics and Lasers in Eng. 53, 2 (2014): 51-59.

[9] Busch J., Blonski J. “Optical Measuring Systems Based on Camera Cluster Systems”. SEAISI Conference \& Exhibition, Singapore, 22-25 May 2017, s. 1-7, http://seaisi.org/seaisi2017/file/file/full-paper/12A-4\%200ptical\%20Measuring\%20System\%20Based\%20on\%20Camera\%20Cluster\%20Systems.pdf (access:12.10.2018).

[10] Kapłonek W. „Teoretyczne i doświadczalne podstawy zastosowania optycznych metod pomiarowych wykorzystujących analizę światła rozproszonego w ocenie stanu powierzchni przedmiotów i narzędzi ściernych w procesach obróbki ściernej". Wydawnictwo Politechniki Koszalińskiej, Koszalin 2017.

[11] Holz R., Hoen K., Weiss K. "Advanced technology in skin pass rolling”. Millenium Steel, 2010, 82-88.

[12] Łukianowicz C., Kapłonek W., Radomska E. „Wykorzystanie zjawiska rozpraszania światła do oceny stanu powierzchni tnących ostrzy technicznych". Stal, Metale \& Nowe Technologie. 3-4 (2017): 36-39. 